\title{
DVIEJŲ ŠOKLUMO IŠTVERMĖS TRENIRUOČIŲ POVEIKIS NERVU IR RAUMENŲ SISTEMŲ NUOVARGIO IR ATSIGAVIMO KAITAI
}

\author{
Dalia Mickevičienė ${ }^{1}$, Albertas Skurvydas ${ }^{1}$, Sigitas Kamandulis ${ }^{1}$, Kazimieras Pukẻnas ${ }^{1}$, Eduardas \\ Rudas $^{1}$, Marius Brazaitis ${ }^{1,}$ Irena Vitkiené ${ }^{1}$, Irina Ramanauskiené $\dot{e}^{1,2}$ \\ Lietuvos kūno kultūros akademijal', Kauno technologijos universitetas ${ }^{2}$, Kaunas, Lietuva
}

\begin{abstract}
Dalia Mickevičienė. Biologijos krypties doktorantė. Lietuvos kūno kultūros akademijos Taikomosios fiziologijos ir sveikatos ugdymo katedros asistentẻ. Mokslinių tyrimų kryptis — įvairaus amžiaus žmonių motorinės sistemos adaptacija prie šoklumo ir šoklumo ištvermės fizinių krūvių.
\end{abstract}

\section{SANTRAUKA}

Tyrimo tikslas - nustatyti, kaip dvi intensyvios šoklumo ištvermès treniruotès veikia raumenu, nervu ir raumenu sistemu nuovargi bei atsigavimq. Sveiki aktyviai nesportuojantys vyrai (amžius $18-20$ metu; $n=11$ ) kas 10 sekundžiu atliko maksimalaus intensyvumo fizini krūvi ( 5 serijas po 20 šuoliu). Krūvio ir atsigavimo metu buvo registruojami šie rodikliai: šnolio aukštis, maksimalioji valinga jèga (MVJ), elektrostimuliavimu sukelta jèga esant skirtingam raumens ilgiui, laktato koncentracija (La) ir kreatinkinazes (CK) aktyvumas kraujyje, raumenu skausmas. Praejus devynioms dienoms po pirmo krūvio, tiriamieji dar karta atliko toki pati krūvī. Tyrimo rezultatai rodo, kad po devyniu dienu kartojant intensyvu šoklumo ištvermès krūvi šuolio aukščio, MVJ ir elektrostimuliavimu sukeltos jègos kaita, kaip ir La koncentracija kraujyje atsigavimo metu, smarkiai nepasikeitè, tačiau sumažèjo CK aktyvumas kraujo plazmoje ir raumens skausmas. Pirmas krūvis labiau paveikè adaptacija prie raumens pažeidos nei prie metabolini nuovargì sukeliančiu veiksniu.

Raktažodžiai: griaučiu raumenys, elektrostimuliavimas, metabolinis nuovargis, raumenu pažeida, pakartoto krūvio efektas.

\section{IVADAS}

$\mathrm{P}$ o kelių dienų (ar net savaičių) pakartojant prieš tai buvusi krūvî, nervų ir raumenu sistemų nuovargis yra mažesnis. Šis organizmo adaptacijos fenomenas yra vadinamas pakartoto krūvio efektu (PKE) (McHugh, Tetro, 2003; Nosaka et al., 2002). Nustatyta, kad PKE ypač pasireiškia tada, kai yra atliekami tokie fiziniai krūviai, kuriu metu raumenys susitraukinejja ekscentriniu režimu (Nosaka, Clarkson, 1995). Tokio darbo metu sukeliama raumenų pažeida, kurią netiesiogiai rodo raumenų skausmas, kraujo baltymų ištekèjimas i kraujotakos sistemą, ilgai trunkantis raumenu jejgos atsigavimas ir kiti rodikliai (Allen, 2001; Nosaka, Clarkson, 1995). Tačiau sportinejje praktikoje retai pasitaiko, kad nuovargis atsirastų tik dèl raumenu pažeidos.
Dažnai taikomi krūviai, kurių metu energijos gamyba raumenyse vyksta anaerobinès glikolizès būdu. Dèl tokių krūvių kyla metabolinis nuovargis: raumens susitraukimo jẻga sumažèja dèl energinių medžiagu (ATP, KP ir glikogeno sumažèjimo) bei metabolitu (neorganinio fosfato, vandenilio jonu ir kt.) koncentracijos padidejjimo (Child et al., 1998; Clarkson, Sayers, 1999; MacIntyre et al., 2001; Martin et al., 2004).

Maksimaliu intensyvu atliekant minutès trukmès šoklumo pratimus, raumenyse gali kilti abiejų tipų nuovargis: metabolinis ir nemetabolinis (Byrne et al., 2004; Morgan, Proske, 2004; Proske, Morgan, 2001). Raumens funkcijos atsigavimą po tokių fizinių krūvių gali lemti ne tik anksčiau minèti veiksniai, bet ir nuovargi kompensuojantys 
mechanizmai. Nèra aišku, kaip metabolinis ir kartu mechaninę raumens pažeidą sukeliantis krūvis veikia PKE.

Tyrimo tikslas - nustatyti, kaip dvi intensyvios šoklumo ištvermès treniruotès veikia raumenų, nervų ir raumenų sistemų nuovargi bei atsigavimą.

\section{TYRIMO METODIKA}

Tiriamieji: sveiki aktyviai nesportuojantys vyrai (amžius 18-22 metai; $\mathrm{n}=11$ ). Jie buvo supažindinti su tyrimo eiga. Tyrimo protokolas aptartas ir patvirtintas Kauno medicinos universiteto biomedicininių tyrimų etikos komitete.

Šoklumo testavimas. Tiriamieji po $10 \mathrm{minu}-$ čiu neintensyvios pramankštos ant daugiakomponentinès jègos platformos (Kistler, $9286 \mathrm{~A}$, Šveicarija) atliko vertikalius šuolius, amortizuojamai pritūpdami per kelių sąnarius iki $90^{\circ}$ kampo (rankos ant juosmens). Remiantis C. Bosco ir P. Komi (1979) metodika, buvo apskaičiuojamas vertikalaus šuolio aukštis (h). Kiekvienas tiriamasis atliko po 3 kontrolinius šuolius. Iskaitomas geriausias šuolio rezultatas.

Šoklumo ištvermès testavimas. Šoklumo ištvermès krūvis: 5 serijos po 20 šuolių (poilsio intervalai tarp seriju -10 s). Šuoliu atlikimo sąlygos šios: 1) kiekvienas šuolis buvo atliekamas šokant kiek galima aukščiau; 2) pritūpimo kampas per kelius $-90^{\circ}$; 3) rankos laikomos ant juosmens. Buvo šuoliuojama ant daugiakomponentinès jègos platformos ir registruojamas kiekvieno šuolio aukštis. Toks pat krūvis taikytas ir ankstesnių tyrimų metu (Skurvydas et al., 2000).

Keturgalvio šlaunies raumens susitraukimo savybių testavimas. Tiriamieji sodinami i specialią kẻdę, dešinè koja per kelio sąnarị nejudamai fiksuojama $90^{\circ}$ ir $135^{\circ} \mathrm{kampu}$. Ant distalinio blauzdos trečdalio buvo dedamas diržas, per traukę sujungtas su metaliniu žiedu. Susitraukiant keturgalviui šlaunies raumeniui, buvo fiksuojamas izometrinis susitraukimas. Jo jèga deformuodavo metalini žiedą, kurio deformaciją tenzodaviklis transformuodavo i elektrinio signalo pokyti. Šis signalas perduodamas i stiprintuvą, o iš jo i personalini kompiuterį, kuriame buvo analizuojama jègos kreivè. Raumens susitraukimo jègos testavimo metodika išsamiau aprašyta ankstesnèse publikacijose (Ratkevičius et al., 1998; Skurvydas, Zachovajevas, 1998; Skurvydas et al., 2000).
Nustatomi šie keturgalvio šlaunies raumens susitraukimo rodikliai:

1. Maksimalioji valinga jèga (MVJ) (atliekami 3 bandymai kas 1 min; registruojamas geriausias rezultatas). MVJ nustatoma, kai koja per kelio sąnari - 90 kampu.

2. Raumens susitraukimo jèga, sukelta stimuliuojant raumeni $1 \mathrm{~Hz}(\mathrm{Pt}), 10 \mathrm{~Hz}(\mathrm{P} 10), 15 \mathrm{~Hz}$ (P 15), $20 \mathrm{~Hz}$ (P 20) ir $100 \mathrm{~Hz}$ (P 100) dažnio elektros stimulais (buvo parinkta tokia stimuliavimo itampa, kuri sukelia didžiausią raumens susitraukimo jègą; stimuliavimo trukmè $-1 \mathrm{~s}$; poilsio intervalas tarp skirtingų stimuliavimo dažnių - $3 \mathrm{~s}$ ). Raumens susitraukimo jèga testuojama tuomet, kai koja per kelio sąnarį nejudamai fiksuojama $135^{\circ}$ (mažas raumens ištempimo ilgis, MI) ir $90^{\circ}$ (didelis raumens ištempimo ilgis, DI) kampu. Pagal P $20 /$ P 100 pokyti buvo nustatomas raumenų mažų dažnių nuovargis (Edwards et al., 1977; Martin et al., 2004; Ratkevičius et al., 1998).

\section{Tyrimo eiga:}

1. Kreatinkinazès (CK) aktyvumas kraujo plazmoje nustatomas automatiniu biocheminiu analizatoriumi „Monarch“ (Instrumentation Laboratory $S p A$, USA-Italy).

2. Laktato (La) koncentracija kraujyje nustatoma pagal Y. U. Kulis ir kt. (1988) metodika.

3. Keturgalvio šlaunies raumens susitraukimo savybès testuojamos tokia tvarka: Pt, P10, P15, P 20, P 100 ir MVJ. Elektrostimuliavimu sukelta jèga pirmiausia testuota fiksuojant koja per kelio sąnari $135^{\circ} \mathrm{kampu}$, paskui $-90^{\circ}$.

4. Atliekama 10 minučiu pramankšta (lètas bėgimas, pulsas bėgimo pabaigoje siekè apie 120 130 tvinksniu per minutę).

5. Šoklumo testavimas (3 šuoliai kas $20 \mathrm{~s}$ ).

6. Šoklumo ištvermès krūvis (5 serijos po 20 šuoliu, poilsis tarp seriju $-10 \mathrm{~s})$.

7. Po šoklumo ištvermès krūvio praejus $3,10,30$ ir 60 minučiu, nustatoma Pt, P 10, P 15, P 20, P 100 ir MVJ.

8. Po šoklumo ištvermès krūvio praejjus 1 ir 60 minučių, nustatomas šuolio aukštis.

9. Po šoklumo ištvermès krūvio praèjus 5 ir 30 minučių, nustatoma La koncentracija kraujyje.

10. Po krūvio praejjus 24 valandoms, nustatomas CK aktyvumas kraujyje ir ivertinamas (subjektyviai) raumenų skausmas pagal 10 balu skalę. Raumenų skausmo įvertinimo metodika taikyta ankstesniuose tyrimuose (Skurvydas et al., 2000). 
Praejjus devynioms dienoms po pirmo krūvio, tiriamieji pakartotinai atliko šoklumo ištvermès krūvị. Testavimo eiga po pirmo ir po pakartoto krūvio buvo tokia pati.

Matematinė statistika. Gauti rezultatai buvo apdoroti matematinès statistikos metodais, apskaičiuojant aritmetinį vidurkị, standartini nuokrypi. Skirtumo tarp aritmetinių vidurkių reikšmingumas nustatytas pagal dvipusi nepriklausomu imčiu Stjudento $t$ kriterijų. Aritmetinių vidurkių skirtumo reikšmingumo lygmuo buvo laikomas svarbiu, kai paklaida mažesnè nei $5 \%(\mathrm{p}<0,05)$.

\section{REZULTATAI}

Tyrimo rezultatai parode, kad pirmo ir antro šoklumo ištvermès krūvio metu vertikalaus šuolio aukštis sumažèjo reikšmingai $(\mathrm{p}<0,05$, lyginant su kontroline reikšme; $p>0,05$, lyginant pirmą ir pakartotą krūvi) ir praèjus 60 minučiu po krūvio grižo iki pradinio dydžio (1 pav.). Po šuolių reikšmingai padidejjo La koncentracija kraujyje ir išliko padidejjusi praejjus 30 minučiu po krūvio (2 pav.). La koncentracija kraujyje po pirmo ir antro krūvio reikšmingai nesiskyrè. Praejus 24 valandoms po pirmo ir antro krūvio, kojų raumenų
1 pav. Vertikalaus šuolio aukščio kitimas krūvio metu (5 serijos po 20 šuolių, poilsis tarp serijų $10 \mathrm{~s}$ ) ir praèjus 1 (A 1) ir 60 (A 60) min po jo
Pastaba. 1 a, 2 a, 3 a, 4 a ir 5 a - šuolio aukštis kiekvienos serijos pradžioje;

1 b, 2 b, 3 b, 4 b ir 5 b- šuolio aukštis kiekvienos serijos pabaigoje.

* — p p $<0,05$, palyginti su 1 a dydžiu.

2 pav. Laktato koncentracijos (La) kraujyje vidutinès reikšmès prieš bei praèjus po pirmo ir pakartoto krūvio 5 (A 5) ir 30 (A 30) min

Pastaba. Šuoliavimo krūvis: 5 serijos po 20 šuoliu, poilsis tarp seriju $-10 \mathrm{~s}$.

* _ $\mathrm{p}<0,05$, palyginti su reikšme prieš krūvi.

3 pav. Kreatinkinazès (CK) aktyvumas kraujyje $\mathbf{1}$ h prieš pirmą bei pakartotą šuoliavimo krūvị ir praèjus 24 h po jų

Pastaba. Šuoliavimo krūvis (5 serijos po 20 šuolių, poilsis tarp seriju - $10 \mathrm{~s})$.

* — p $<0,05$, palyginti su reikšme prieš krūvị; \#$\mathrm{p}<0,05$, palyginti su reikšme po pirmo krūvio.
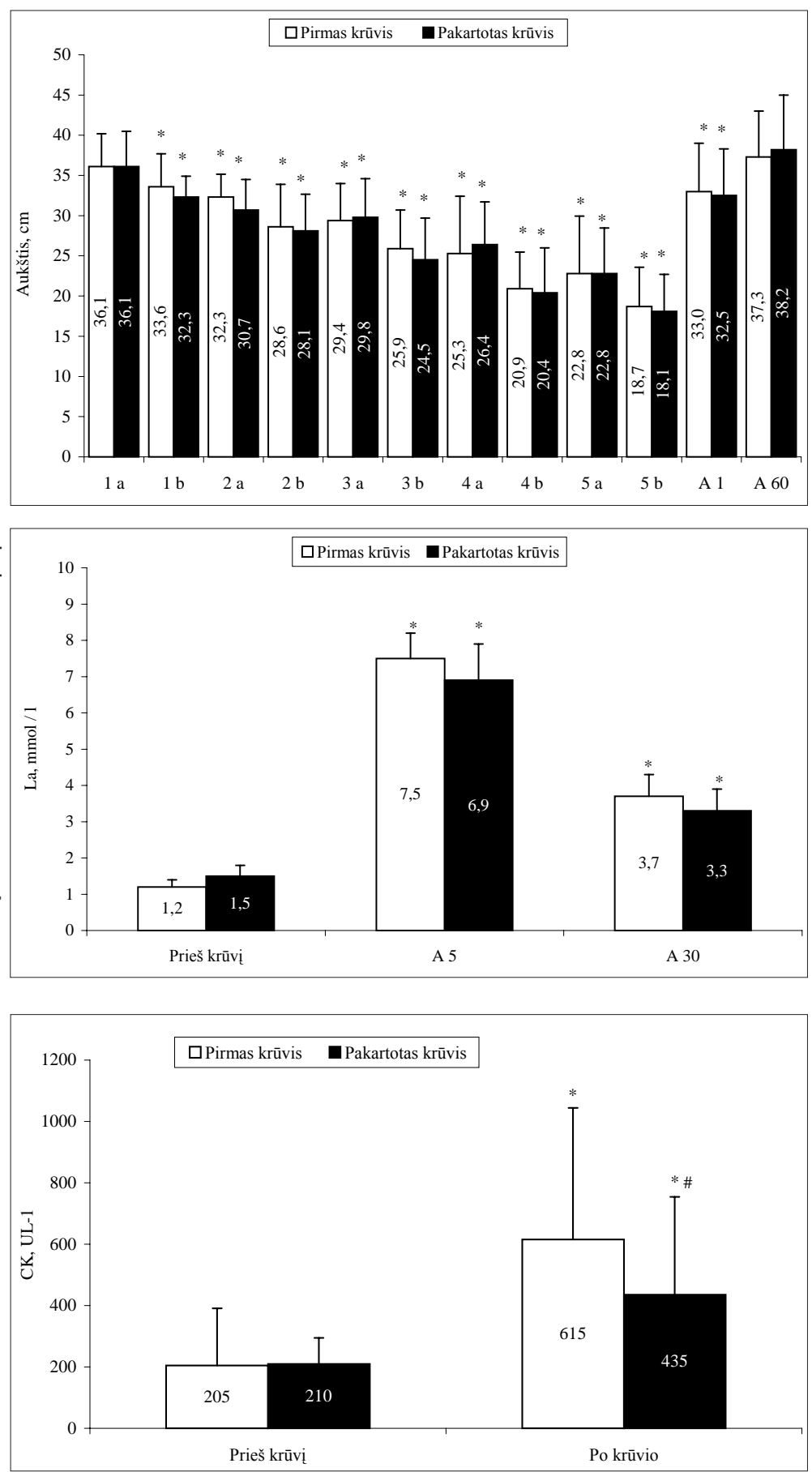


\begin{tabular}{|c|c|c|c|c|c|}
\hline Krūvis & $\begin{array}{c}\text { Kampas per } \\
\text { kelius, } \\
\text { laipsniai }\end{array}$ & P 20, N & P 100, N & P 20 / P 100 & MVJ, N \\
\hline \multirow{5}{*}{ Pirmas } & 90 & 233,7 & 266,1 & 0,87 & \\
& 135 & 27,4 & 82,2 & 0,08 & 495,8 \\
& & 78,1 & 454,4 & 0,61 & 82,2 \\
& 90 & 225,7 & 276,7 & 0,86 & \\
& & 62,2 & 76,7 & 0,08 & 507,1 \\
& 135 & 268,8 & 439,9 & 0,6 & 94,5 \\
& & 65,9 & 121,1 & 0,09 & \\
\hline
\end{tabular}

Lentelè. Keturgalvio šlaunies raumens maksimaliosios valingos jègos (MVJ) ir 20 (P 20) bei 100 (P 100) Hz stimuliavimo dažniais sukeltos jègos reikšmès prieš pirmą ir pakartotą krūvi

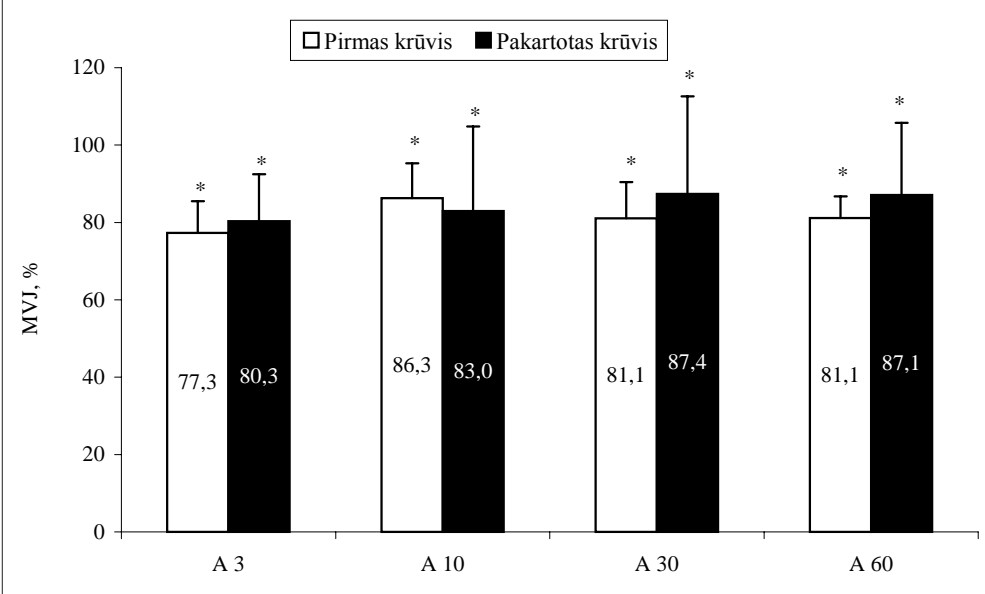

4 pav. Keturgalvio šlaunies raumens maksimaliosios valingos jẻgos (MVJ) vidutinės reikšmės

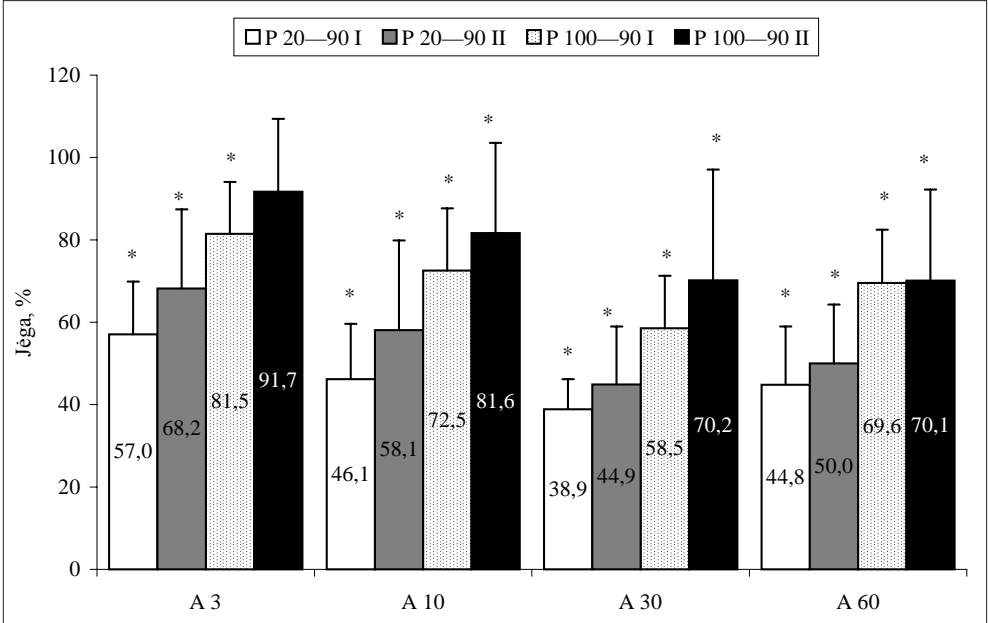

5 pav. Didelio ilgio keturgalvio šlaunies raumens susitraukimo jègos vidutinès reikšmès, sukeltos raumenị stimuliuojant 20 (P 20) ir 100 (P 100) Hz dažnio elektros stimulais

Pastaba. Vidutinès reikšmès procentais pateiktos (lyginant su reikšmėmis, užregistruotomis prieš krūvị) po pirmo (I) bei pakartoto (II) krūvio praẻjus 3 (A 3), 10 (A 10), 30 (A 30) ir 60 (A 60) min. Šuoliavimo krūvis: 5 serijos po 20 šuoliu, poilsis tarp seriju - $10 \mathrm{~s}$ ). 90 - koja per kelio sąari $90^{\circ} \mathrm{kampu} . *-\mathrm{p}<0,05$, palyginti su reikšme prieš krūvị.

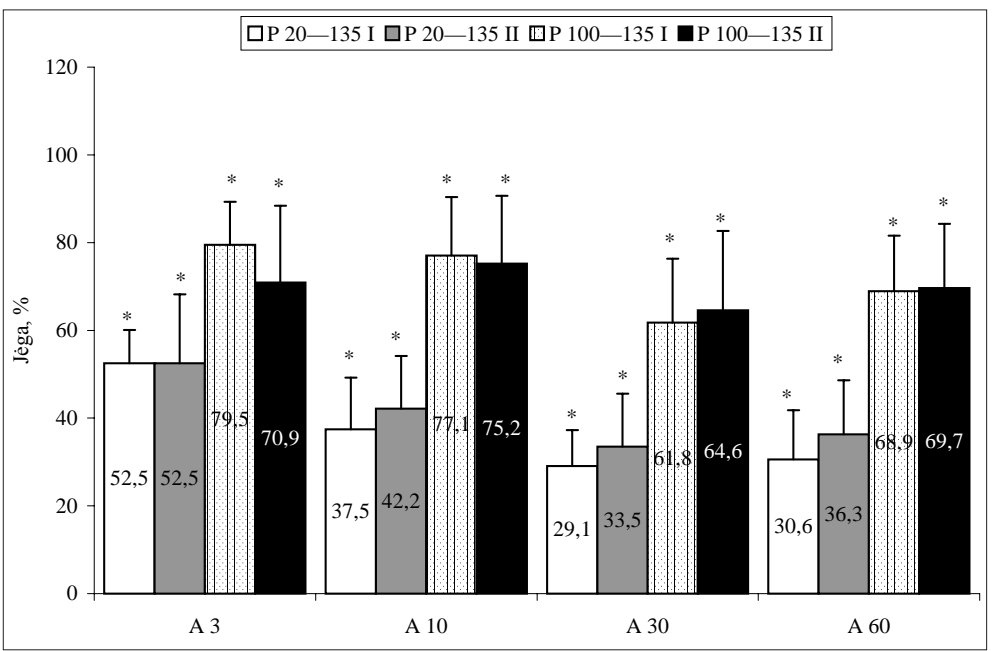

6 pav. Mažo ilgio keturgalvio šlaunies raumens susitraukimo jėgos vidutinès reikšmès, sukeltos stimuliuojant raumeni 20 (P 20) ir 100 (P 100) Hz dažnio elektros stimulais

Pastaba. Vidutinès reikšmès procentais pateiktos (lyginant su reikšmėmis, užregistruotomis prieš krūvi) po pirmo (I) bei pakartoto (II) krūvio praejjus 3 (A 3), 10 (A 10), 30 (A 30) ir 60 (A 60) min. Šuoliavimo krūvis: 5 serijos po 20 šuoliu, poilsis tarp seriju -10 s. 135 - koja per kelio sąnarį $135^{\circ}$ kampu. * _ $\mathrm{p}<0,05$, palyginti su reikšme prieš krūvị. 
7 pav. Keturgalvio šlaunies raumens skausmas praèjus 24 valandoms po pirmo ir pakartoto šuoliavimo krūvio

Pastaba. Šuoliavimo krūvis: 5 serijos po 20 šuolių, poilsis tarp seriju - $10 \mathrm{~s}$.

\#- $\mathrm{p}<0,05$, palyginti su reikšme po pirmo krūvio.

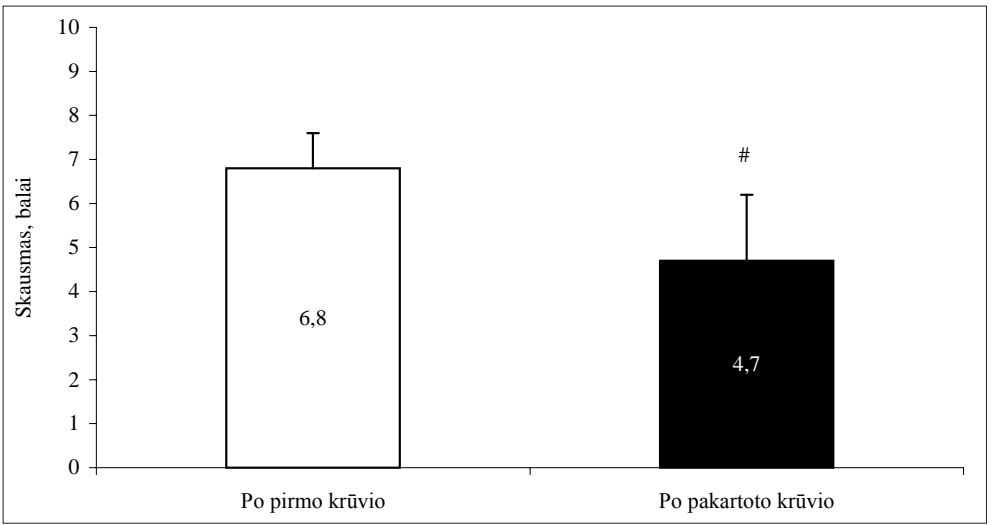

skausmas buvo atitinkamai $6,8 \pm 0,8$ ir $4,7 \pm 1,1$ balų ( $\mathrm{p}<0,05$, lyginant pirmą ir pakartotą krūvi) (7 pav.). CK aktyvumas kraujo plazmoje po antro krūvio praejjus 24 valandoms buvo mažesnis nei tuo pačiu metu po pirmo krūvio $(\mathrm{p}<0,05)$ (3 pav.).

Po šoklumo ištvermès krūvio (abiejų krūvių metu) reikšmingai sumažèjo MVJ (4 pav.) ir visu stimuliavimo dažnių sukelta jèga (žr. lent.) (raumeniui esant mažo (MI) ir didelio (DI) ilgio, išskyrus tuos atvejus, kai dideliu stimuliavimo dažnių sukelta jèga, raumeniui esant DI, iš karto po krūvio reikšmingai nepakito) ir neatsigavo iki pradinio lygio per 60 minučiu po krūvio (5 ir 6 pav.). Daugiau sumažèjo mažų $(20 \mathrm{~Hz})$ nei didelių $(100 \mathrm{~Hz})$ stimuliavimo dažnių sukelta jèga $(\mathrm{p}<0,05$, lyginant mažų ir didelių stimuliavimo dažnių sukeltas jëgas). MVJ ir stimuliavimu sukeltos jẻgos atsigavimas per pirmąsias 60 minučiu po pirmo ir po pakartoto krūvio reikšmingai nesiskyrè.

\section{REZULTATŲ APTARIMAS}

Atlikto tyrimo rezultatai rodo, kad dvi intensyvios šoklumo ištvermès treniruotès: 1) nepadidino kojų raumenų susitraukimo jẻgos, šoklumo ir šoklumo ištvermės; 2) nepadidino šuolio aukščio, MVJ ir elektrostimuliavimu sukeltos jègos atsigavimo tempo; 3 ) sumažino raumens mechaninę pažeidą (rodikliai - CK ir raumenų skausmas).

Nėra abejonès, kad atliktas krūvis sukèlè dviejų tipų nuovargi - metabolini ir nemetabolini. Metabolinio nuovargio procesą rodo ryškus laktato koncentracijos padidejimas po fizinio krūvio (2 pav.), o nemetabolini — raumens skausmas ir kretinkinazès aktyvumo padidejjimas kraujo plazmoje (3 ir 7 pav.). Be to, nemetabolinio nuovargio kilmę rodo mažų dažnių nuovargio poreiškis. Mažai yra abejonių, kad maksimaliu intensyvumu atliekant 5 serijas po 20 šuolių (kas 10 s) nuovargis atsiranda ne tik raumenyse, bet ir nervu sistemoje. Atlikta nemažai tyrimų, rodančių, kad fizinius pratimus atliekant maksimaliu intensyvumu nuovargis gali atsirasti keliose nervu ir raumenų sistemų vietose (Fitts, 1994; Gandevia, 2001). Jei labiau sumažèja elektrostimuliavimu sukelta jèga nei MVJ, tai galima teigti, kad nuovargis labiau pasireiškè raumenyse negu nervu sistemoje (Gandevia, 2001). Atlikto tyrimo atveju raumens susitraukimo jèga, sukelta mažu stimuliavimo dažnių, labiau sumažèjo nei MVJ (4, 5 ir 6 pav.). Mažų stimuliavimo dažnių sukeltos jègos sumažejjimas priklauso nuo iš sarkoplazminio tinklo išmetamo kalcio jonų koncentracijos sumažejimo ir nuo miofibriliu jautrumo kalcio jonams, kai tuo tarpu dèl šiu priežasčių atsiradusi dideliu stimuliavimo dažniu jèga mažiau pakinta (Westerblad, Allen, 2002).

Viena treniruotè nepadidino raumens maksimaliosios jègos, šoklumo ir šoklumo ištvermès krūvị kartojant po devynių dienų. Raumens atsparumas nuovargiui pirmo ir pakartoto krūvio metu išliko toks pat, tačiau po krūvio praejus 24 valandoms sumažèjo raumens mechaninès pažeidos simptomai: CK aktyvumas kraujo plazmoje ir raumenu skausmas. Manome, kad raumens mechaninès pažeidos sumažejimas dèl dvieju treniruočių gali būti paaiškinamas raumenu ir (ar) nervų sistemos adaptacija. Dél nervų sistemos adaptacijos galejo pasikeisti judesių valdymo ekonomiškumas, pavyzdžiui, kartojant krūvì, vis labiau i darbą galèjo būti ịtraukiamos lètojo susitraukimo raumeninès skaidulos, kurios atsparesnès nuovargiui nei greitosios (Fitts,1994). Be to, kartojant krūvị, raumens apkrova galèjo pasiskirstyti tarp didesnio kiekio raumeninių skaidulų, 
kartu buvo išvengta ypač didelio labiausiai pažeidžiamų raumeninių skaidulų mechaninio streso.

Jeigu nervinè PKE hipotezė būtų neteisinga, t. y. raumenys pirmos treniruotès metu patiria toki pati mechanini stresą, kaip ir atliekant pirma treniruotę, tai mažesnę raumenų mechaninę pažeidą būtų galima paaiškinti raumenų adaptacija. Aptinkama keletas aiškinimų, kodèl raumuo pasidaro atsparesnis mechaninei pažeidai. Viena iš labiausiai paplitusiu hipoteziu teigia, kad PKE pasireiškia dèl to, kad raumeninèje skaiduloje padidejja sarkomerų skaičius ir sustiprejja silpnieji, mechaninei pažeidai jautriausi sarkomerai (Lynn et al., 1998). Nustatyta, kad 5 treniruotes atliekant ekscentrinius fizinius pratimus padidejja sarkomeru skaičius (Lynn et al., 1998), bet nèra aišku, ar jis gali padidèti po vienos treniruotès.

Raumens funkcijos atsigavimas po tokiu fiziniu krūvių, kurių metu pasireiškia metabolinis ir nemetabolinis nuovargis, yra gana sudètingas. Jei atsigavimo metu metabolinis nuovargis greitai išnyksta (Fitts, 1994; Sahlin et al., 1998), tai dèl raumens mechaninès pažeidos atsiradęs nemetabolinis nuovargis gali dar labiau padidèti (Allen, 2001; Friden, Lieber, 2001). Tyrimo rezultatai parode, kad raumens atsigavimo metu (iki $60 \mathrm{~min}$ ) La koncentracija kraujyje, kaip ir raumens susitraukimo jègos kaita, po pirmo ir pakartoto krūvio reikšmingai nesiskyrè. Manome, kad pirmas krūvis mažiau veikia raumens adaptaciją prie metaboliniu veiksnių nei raumens pažeidos. PKE gali būti susijęs su vèlesniais atsigavimo etapais vykstančiais procesais: uždegimu ir raumens regeneracija (McHugh, 2003). Nustatyta, kad po pakartoto krūvio sumažèja neutrofilų ir monocitų aktyvacija (Pizza et al., 1996), t. y. raumenyse kyla mažesnis uždegimas. Sumažèjęs uždegimas gali būti susijęs su ląstelinių struktūrų sustiprejjimu, todèl mažiau pažeidžiamos miofibrilès (Lapointe et al., 2002). J. Y. Yu ir kt. (2003) nustate, kad po intensyvaus fizinio krūvio raumeninèje ląstelèje padaugèjo desmino ir aktino, o tai rodo atsigavimo metu suaktyvejjusią baltymų sintezę.

\section{IŠVADOS}

Po devynių dienų kartojant intensyvų šoklumo ištvermès krūvit, šuolio aukščio, MVJ ir elektrostimuliavimu sukeltos jègos kaita, kaip ir La koncentracija atsigavimo metu, smarkiai nepasikeite, tačiau sumažèjo CK aktyvumas kraujo plazmoje ir raumens skausmas. Pirmas krūvis labiau paveike adaptaciją prie raumens pažeidos nei prie metabolinị nuovargi sukeliančių veiksnių.

\section{LITERATŪRA}

Allen, D. G. (2001). Eccentric muscle damage: Mechanisms of early reduction of force. Acta Physiologica Scandinavica, 171 (3), 311-319.

Bosco, C., Komi, P. (1979). Mechanical characteristics and fiber composition of human leg extensors muscles. European Journal of Applied Physiology, 41, 275-284.

Byrne, C., Twist, C., Eston, R. (2004). Neuromuscular function after exercise-induced muscle damage. Theoretical and applied implications. Sports Medicine, 34 (1), 49-69.

Child, R. B., Saxton, J. M., Donnelly, A. E. (1998). Comparison of knee extensor muscle actions on indices of damage and angle-specific force production in humans. Journal of Sports Science, 16, 301-308.

Clarkson, P. M., Sayers, S. P. (1999). Etiology of exerciseinduced muscle damage. Canadian Journal of Applied Physiolgy, 24 (3), 234-248.

Edwards, R. H., Hill, D. K., Jones, D. A., Merton, P. A. (1977). Fatigue of long duration in human skeletal muscle after exercise. Journal of Physiology, 272, 769-778.

Fitts, R. H. (1994). Cellular mechanisms of muscle fatigue. Physiological Reviews, 7 (1), 49-95.

Friden, J., Lieber, R. L. (2001). Serum creatine kinase level is a poor predictor of muscle function after injury. Scandinavian Journal of Medicine and Science in Sports, $11(2), 126-127$.
Gandevia, S. C. (2001). Spinal and supraspinal factors in human muscle fatigue. Physiological Reviews, 81 (4), 1725-1789.

Kulis, Yu, Laurinavichyus, A., Firantas, S. G., Kurtinaitenè, B. S. (1988). Determination of lactic acid in blood with an exan-G analyzer. Journal of Analytical Chemistry, 43 (7), 1521-1523.

Lapointe, B. M., Fremont, P., Cote, C. H. (2002). Adaptation to lenghtening contractions is independent of voluntary muscle recruitment but relies on inflammation. Americal Journal of Physiology - Regulatory, Integrative and Comparative Physiology, 282, R 323-329.

Lynn, R., Talbot, J. A., Morgan, D. L. (1998). Differences in rat skeletal muscles after incline and decline running. Journal of Applied Physiology, 85 (1), 98-104.

MacIntyre, D. L., Sorichter, S., Mair, J., Berg, A., McKenzie, D. C. (2001). Markers of inflammation and myofibrillar proteins following eccentric exercise in humans. European Journal of Applied Physiology, 84 (3), $180-186$.

Martin, V., Millet, G. Y., Martin, A., Deley, G., Lattier, G. (2004). Assessment of low-frequency fatigue with two methods of electrical stimulation. Journal of Applied Physiology, 97, 1923-1929.

McHugh, M. P. (2003). Recent advances in the understanding of the repeated bout effect: the protective effect against muscle damage from a single bout of 
eccentric exercise. Scandinavian Journal of Medicine and Science in Sports, 13 (2), 88-97.

McHugh, M. P., Tetro, D. T. (2003). Changes in the relationship between joint angle and torque production associated with the repeated bout effect. Journal of Sports Sciences, 21 (11), 927-932.

Morgan, D. L., Proske, U. (2004). Popping sarcomere hypothesis explains stretch-induced muscle damage. Clinical and Experimental Pharmacology and Physiology, $31(8), 541-545$.

Nosaka, K., Clarkson, P. M. (1995). Muscle damage following repeated bouts of high force eccentric exercise. Medicine and Science in Sports and Exercise, 27 (9), $1263-1269$.

Nosaka, K., Newton, M., Sacco, P. (2002). Delayed-onset muscle soreness does not reflect the magnitude of eccentric-induced muscle damage. Scandinavian Journal of Medicine and Science in Sports, 12, 337-346.

Pizza, F. X., Davis, B. H., Hendrickson, S. D. et al. (1996). Adaptation to eccentric exercise: Effect on CD64 and CD11b / CD18 expression. Journal of Applied Physiology, 80, 47-55.

Proske, U., Morgan, D. L. (2001). Muscle damage from eccentric exercise: Mechanism, mechanical signs, adaptation and clinical applications. Journal of Physiology, 537, 2, 333-345.
Ratkevicius, A., Skurvydas, A., Pavilionis, E., Quistorf, B., Lexell, J. (1998). Effects of contraction duration on low-frequency fatigue in voluntary and electrically induced exercise of quadriceps muscle in humans. European Journal of Applied Physiology, 77, 462-468.

Sahlin, K., Tonkonogi, M., Söderlund, K. (1998) Energy supply and muscle fatigue in humans. Acta Physiologica Scandinavica, 162, 261-266.

Skurvydas, A., Jascaninas, J., Zachovajevas, P. (2000). Changes in height of jump, maximal voluntary contraction force and low-frequency fatigue after 100 intermittent or continuous jumps with maximal intensity. Acta Physiologica Scandinavica, 169 (1), 55-62.

Skurvydas, A., Zachovajevas, P. (1998). Is post-tetanic potentiation, low frequency fatigue (LFF) and postcontractile depression (PCD) coexistent in intermittent isometric exercises of maximal intensity? Acta Physiologica Scandinavica, 164 (2), 127-133.

Westerblad, H., Allen, D. G. (2002). Recent advances in the understanding of skeletal muscle fatigue. Current Opinion in Rheumatology, 14 (6), 648-652.

Yu, J. G., Furst, D. O., Thornell, L. E. (2003). The mode of myofibril remodeling in human skeletal muscle effected by DOMS induced by eccentric contraction. Journal of Histochemistry and Cell Biology, 119 (5), $383-393$.

\title{
EFFECT OF TWO JUMPING ENDURANCE TRAININGS ON FATIGUE AND RECOVERY DYNAMICS OF NEURO-MUSCULAR SYSTEM
}

\author{
Dalia Mickevičienè ${ }^{1}$, Albertas Skurvydas ${ }^{1}$, Sigitas Kamandulis ${ }^{1}$, Kazimieras Pukẻnas ${ }^{1}$, Eduardas \\ Rudas $^{1}$, Marius Brazaitis ${ }^{1}$ Irena Vitkiené ${ }^{1}$, Irina Ramanauskienè $\dot{e}^{1,2}$ \\ Lithuanian Academy of Physical Education ${ }^{1}$, Kaunas University of Technology ${ }^{2}$, Kaunas, Lithuania
}

\begin{abstract}
The aim of the study was to establish the effect of two trainings aimed at developing jumping endurance on the fatigue and recovery dynamics of neuro-muscular system. The subjects were healthy men $(n=11)$, not actively engaged in sports (18-20 years of age). They performed five series of 20-jump (with $10 \mathrm{~s}$ rest between series) exercise bout. The following data were measured: the force of the quadriceps muscle, aroused by electrical stimulation at different lengths, maximal voluntary contraction force (MVC), height of jump, muscle soreness, lactate (La) concentration and creatinkinase (CK) activity in the blood during exercise and at recovery after the end of exercise bout. The same exercise bout was repeated at nine days after the first bout. The results of the research done indicate that within nine days in the course of repeating jumping exercise bout the height of the jump, force induced by electrostimulation and MVC dynamics, as well as La concentration at recovery did not change significantly, however, CK activity and muscle soreness decreased. The first exercise bout has greater effect on adaptation to muscle damage than to metabolic factors.
\end{abstract}

Keywords: quadriceps muscle, electrostimulation, metabolic fatigue, muscle damage, repeated bout effect.

Gauta 2005 m. vasario 13 d.

Received on February 13, 2005

Priimta 2005 m. gegužès 18 d.

Accepted on May 18, 2005
Dalia Mickevičienè

Lietuvos kūno kultūros akademija

(Lithuanian Academy of Physical Education)

Sporto g. 6, Lt-44221 Kaunas

Lietuva (Lithuania)

Tel +37037302677

E-mail d.mickeviciene@1kka.1t 